\title{
Diversity, abundance, and biomass production of bacterial groups in the western Arctic Ocean
}

\author{
Rex R. Malmstrom ${ }^{1,2}$, Tiffany R. A. Straza ${ }^{1}$, Matthew T. Cottrell ${ }^{1}$, David L. Kirchman ${ }^{1, *}$ \\ ${ }^{1}$ College of Marine and Earth Studies, University of Delaware, Lewes, Delaware 19958, USA \\ ${ }^{2}$ Present address: Department of Civil and Environmental Engineering, Massachusetts Institute of Technology, Cambridge, \\ Massachusetts 02139, USA
}

\begin{abstract}
To better understand links between the diversity and activity of bacterial communities in the Arctic Ocean, the surface waters of the Chukchi Sea were examined by clone library analysis and by a combination of fluorescence in situ hybridization (FISH) and microautoradiography. About $60 \%$ of the $16 \mathrm{~S}$ rRNA sequences from the library had closest BLAST hits to bacteria found previously in the Arctic, and some of these sequences appear to be restricted to polar waters. The number of operational taxonomic units in the library dropped by more than half when sequences were grouped at $99 \%$ sequence similarity, indicating that the library was composed of several bacterial clusters with high sequence similarity. Oligonucleotide probes were designed to enumerate some bacterial groups found in the clone library such as the Arctic96B-16 cluster, Roseobacter RCA cluster, AGG58 cluster, and Polaribacter clade. FISH analyses revealed that each of these groups typically accounted for 3 to $10 \%$ of prokaryotes, while well known cosmopolitan groups like the SAR86 and SAR11 clades made up 8 and $25 \%$ of the prokaryotic communities, respectively. Overall, $>60 \%$ of total prokaryotes belonged to 8 specific bacterial groups, of which the SAR11 clade was the most diverse $(<13 \% 16 \mathrm{~S}$ rRNA sequence difference). Together the Arctic96B-16, Roseobacter RCA, Polaribacter, and SAR11 clades also accounted for 25 to $82 \%$ of biomass production at 4 locations, as determined by a combination of FISH and microautoradiography of ${ }^{3} \mathrm{H}$-leucine assimilation. These results indicate that community composition and biomass production in the western Arctic Ocean are dominated by a few bacterial groups.
\end{abstract}

KEY WORDS: Arctic Ocean · Clone library - Microautoradiography · FISH · SAR11 clade · Roseobacter clade $\cdot$ SAR86 clade $\cdot$ Leucine uptake

\section{INTRODUCTION}

The application of PCR-based methods and shotgunsequencing of environmental gene sequences has revealed the great diversity of bacterial communities in the ocean (Giovannoni \& Rappé 2000, Venter et al. 2004). It has been hypothesized that these diverse bacterial assemblages may be composed of ecotypes, that is, groups of closely related bacteria that fill similar ecological roles (Cohan 2002, Giovannoni 2004). Recent work on Massachusetts coastal waters, which used various techniques to minimize PCR errors, suggested that most of the bacterial 16S rRNA gene sequences could be placed into groups of $\geq 99 \%$ sequence similarity (Acinas et al. 2004). This tight clustering of bacteria would be expected if marine bacterial assemblages were composed of ecotypes. However, the ecological significance of groups with $\geq 99 \%$ sequence similarity is unclear, and it is unknown if this type of clustering is even common in the ocean. Analogous investigations of other marine environments are necessary to determine the prevalence and possible ecological significance of bacterial groups of high sequence similarity.

The diversity and organization of bacterial communities has been investigated most extensively in tem- 
perate waters, while other environments like the Arctic Ocean remain under-sampled (Bano \& Hollibaugh 2002, Pommier et al. 2005). Microbial communities in the Arctic Ocean face different selection pressures than those found in temperate and tropical regions, such as perennially low water temperatures and strong seasonal patterns in ice cover and solar irradiance. These environmental factors could select for bacterial assemblages that are distinct from those found in temperate and tropical regions. Direct comparisons have been difficult, however, because little is known about the composition of bacterial communities in Arctic waters. For example, it is unclear if Arctic assemblages are composed of many bacterial clusters with high $16 \mathrm{~S}$ rRNA gene sequence similarity, as has been found in temperate coastal waters (Acinas et al. 2004). Further investigation into Arctic bacterial assemblages is needed to determine if they are composed of these microdiverse bacterial clusters.

Determining the abundance and distribution of specific microdiverse clusters, as well as broader groups, is an important step in understanding the ecological role of bacterial groups comprising Arctic assemblages. Fluorescence in situ hybridization (FISH) can be used to examine the abundance and distribution of phylogenetically related bacteria (Amann et al. 1995). Quantitative data from FISH analyses complement results from clone libraries and can also provide information about bacterial groups that appear to be underrepresented in clone libraries. For example, members of the Bacteroidetes phylum can account for a larger fraction of bacterial assemblages than their abundance in clone libraries suggests (Cottrell \& Kirchman 2000, Kirchman et al. 2003). In addition, FISH can be combined with microautoradiography (micro-FISH) to track the assimilation of ${ }^{3} \mathrm{H}$-leucine, an index of bacterial biomass production, by specific bacterial groups (Cottrell \& Kirchman 2003, Malmstrom et al. 2005, Longnecker et al. 2006). Both FISH and micro-FISH data are needed along with clone library analyses to identify the bacterial groups dominating Arctic communities and to determine their potential ecological impact.

In this study, we used FISH, micro-FISH, and clone library analyses to better understand the composition and activity of bacterial assemblages in the Arctic Ocean. Initially, a clone library of 16S rRNA genes was constructed from surface waters of the Chukchi Sea. This library was used to identify clusters of bacteria with different levels of sequence similarity, and to design fluorescent oligonucleotide probes for both highly similar clusters and more diverse groups of bacteria. Using these probes, the abundance of bacterial groups was determined at several locations and during different months in the Arctic. In addition, leucine assimilation by select bacterial groups was examined at 4 locations using micro-FISH. We found that the clone library was composed of clusters of bacteria with high sequence similarity, and that some of these clusters could account for a substantial fraction of total prokaryotes and biomass production in surface waters of the western Arctic Ocean.

\section{MATERIALS AND METHODS}

Sample collection. As part of the Shelf-Basin Interaction project (Grebmeier \& Harvey 2005), 51 of seawater were collected from $20 \mathrm{~m}$ in the Chukchi Sea $\left(73.096^{\circ} \mathrm{N}\right.$, $154.37^{\circ} \mathrm{W}$ ) on June 13,2004 , for the construction of a clone library (Fig. 1). Seawater was pre-filtered through a $0.8 \mu \mathrm{m}$ polycarbonate filter (Poretics), and bacteria were collected on a $0.2 \mu \mathrm{m}$ filter (Durapore) that was then stored in sucrose buffer $\left(0.75 \mathrm{~mol} \mathrm{l}^{-1}\right.$ sucrose, $400 \mathrm{mmol} \mathrm{l}^{-1} \mathrm{NaCl}, 20 \mathrm{mmol} \mathrm{l}^{-1}$ EDTA, and $50 \mathrm{mmol} \mathrm{l}^{-1}$ Tris- $\mathrm{HCl} \mathrm{pH} 9.0$ ) at $-80^{\circ} \mathrm{C}$ prior to DNA extraction and library construction. Environmental parameters measured at the time of sampling were temperature $-1.5^{\circ} \mathrm{C}$, salinity 30.86, oxygen $406 \mu \mathrm{M}$, nitrate $0.6 \mu \mathrm{M}$, ammonium $0.2 \mu \mathrm{M}$, and phosphate $0.8 \mu \mathrm{M}$.

Whole seawater was collected from surface waters (5 to $30 \mathrm{~m}$ ) for FISH analysis at 25 locations in the Arctic Ocean during spring and summer of 2002 and 2004 (Fig. 1). Sample water was fixed with paraformaldehyde ( $2 \%$ final concentration), preserved overnight at $4{ }^{\circ} \mathrm{C}$, filtered $(20$ to $100 \mathrm{ml}$ ) onto white polycarbonate filters $(0.2 \mu \mathrm{m})$, rinsed with deionized water, and stored at $-20^{\circ} \mathrm{C}$ for later analysis using FISH.

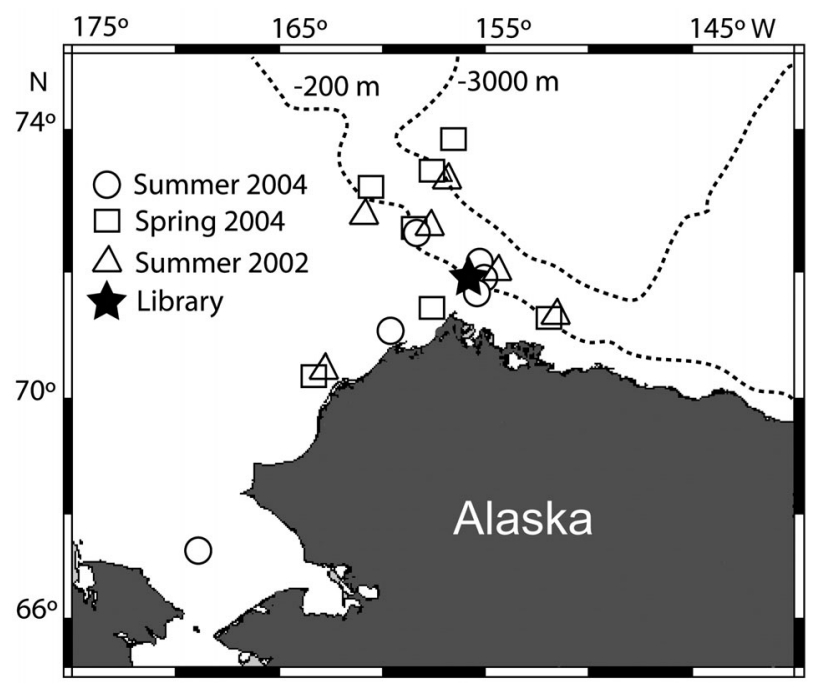

Fig. 1. Stations sampled in the Arctic Ocean for FISH analyses and for the construction of a $16 \mathrm{~S}$ rDNA library 
Bacterial biomass production was estimated from total leucine incorporation rates (Kirchman 2001). Triplicate seawater samples were incubated with $20 \mathrm{nmol}$ $\mathrm{l}^{-1}{ }^{3} \mathrm{H}$-leucine for $2 \mathrm{~h}$ at in situ temperatures. Incorporated ${ }^{3} \mathrm{H}$-leucine was collected by microcentrifugation and activity measured using liquid scintillation counting (Smith \& Azam 1992). Biomass production was calculated using a conversion factor of $1.5 \mathrm{~kg} \mathrm{C} \mathrm{mol}^{-1}$ of incorporated leucine, which assumes no isotope dilution (Kirchman 2001).

Clone library construction and analysis. Community DNA was isolated from filters with a phenol/ chloroform extraction and ethanol precipitation. Purified DNA provided a template for 10 replicate PCR reactions (110 ng DNA per reaction) using universal bacterial primers $27 \mathrm{f}$ and $1492 \mathrm{r}$ for the $16 \mathrm{~S}$ rRNA gene (Lane 1991). To reduce the formation of heteroduplexes, the PCR reactions were reconditioned after 15 amplification cycles by diluting PCR products 10-fold with fresh PCR cocktail and performing an additional 3 cycles of amplification (Thompson et al. 2002, Acinas et al. 2004). PCR products were pooled and concentrated on a spin filter (Microcon YM-100), and were cloned with a PCR 2.1-TOPO kit (Invitrogen). Inserts were sequenced using universal bacterial primers $27 \mathrm{f}$ and 907r (Lane 1991) on a SpectraMedix sequencer using a BigDye Terminator 3.1 kit (Applied Biosystems).

No chimeras were found in the library using Bellerophon (Huber et al. 2004) and Chimera-Check (Cole et al. 2003), but 5 plastid sequences were identified and removed from the analyses. The DOTUR program was used to group the remaining 139 clones at various sequence similarity levels (e.g. 100, 99, 97 \%) (Schloss \& Handelsman 2005). The DOTUR program also calculated the Chao-1 estimator and the ShannonWiener index of diversity for the Arctic library. ARB and PHYLIP were used to construct neighbor-joining trees using the Jukes-Cantor correction (Felsenstein 2004, Ludwig et al. 2004). Analyses of the Arctic library with DOTUR, ARB, and PHYLIP were based on alignments of sequences from Escherichia coli positions 98 to 845 .

The diversity of the Arctic library was compared directly with the Massachusetts coastal library reported previously (Acinas et al. 2004). Because some sequences in the Massachusetts coastal library were shorter than those in the Arctic library, diversity calculations for both libraries were based on sequence data from E. coli positions 170 to 636 to ensure sequence overlap. The Massachusetts coastal library also had more clone sequences (547 sequences) than the Arctic library (139 sequences), so the DOTUR program was used to generate diversity estimates for the Massachusetts coastal library based on multiple random samplings of 139 sequences.

Development and application of FISH probes. Fluorescent oligonucleotide probes were designed using ARB to quantify bacteria belonging to 6 phylogenetic groups occurring in the Arctic clone library (Table 1). Redundant probes were designed for bacterial groups when possible, and probe sequences were screened against 16S rRNA sequences from the 'Ribosomal Database Project' (Cole et al. 2003) to determine speci-

Table 1. Oligonucleotide sequences for FISH probes designed in this study. Competitor probes: these unlabeled probes were used with corresponding Cy3-labeled probes (e.g. SAR86-677 and compSAR86-677) to minimize non-specific hybridization of the labeled probes

\begin{tabular}{lll}
\hline Probe name & \multicolumn{1}{c}{ Probe sequence $\left(5^{\prime} \rightarrow 3^{\prime}\right)$} & Target group \\
\hline Arctic96B16-196 & GTC TGT AAA CAG ATC CCC TCC T & Arctic96B-16 cluster \\
Arctic96B16-728 & GTA TCA AGC CAG GGC GTC GCC T & Arctic96B-16 cluster \\
Arctic96B16-734 & GTG TCA GTA TCA AGC CAG GGC G & Arctic96B-16 cluster \\
Arctic96A14-441 & GTC TTA AGC TGT TCC TCC CTA C & Arctic96A-14 cluster \\
SAR86-733 & TGT CAG TAC AGA TCC AGG AGG C & SAR86 clade \\
SAR86-677 & GCA TTC CAC CGC TAC ACT ATG A & SAR86 clade \\
compSAR86-677 & GCA TTC CAC CGC TAC ACT GTG A & Competitor probe \\
SAR86-213 & AGG CTC ATC TAG TAG CGA AAG C & SAR86 clade \\
compSAR86-213 & AGG CTC ATC TAA TAG CGA GAG C & Competitor probe \\
Polaribacter-740 & CCC TCA GCG TCA GTA CAT ACG T & Polaribacter cluster \\
Polaribacter-218 & GAC GCA TAG CCA TCT TTT ACC G & Polaribacter cluster \\
compPolaribacter-218 & GAC GCA TGC GCA TCT TTT ACC G & Competitor probe \\
AGG58-145 & CCA CAT TTC TAT GGG CTA TCC C & AGG58 cluster branch 2 \\
compAGG58-145 & CCA AAT TTC TCT GGG CTA TCC C & Competitor probe \\
Arctic-Roseo-845 & CCG TTA GTG TGA CAC CAA CAA G & Roseobacter RCA cluster \\
Roseo-RCA-845 & CCG TTA GGT GTG ACA CCA ACA AG & Roseobacter RCA cluster \\
\hline
\end{tabular}


ficity. Arctic SAR86 sequences were recognized by at least 2 of 3 probes, while the other probes matched all sequences within the targeted group. Unlabeled competitor probes (Manz et al. 1992) were also designed for some groups to ensure the specificity of hybridization (Table 1). Hybridization buffer containing 30\% formamide was selected over $20 \%$ formamide because it provided higher stringency, although no statistical differences were found at 3 locations in the Arctic where formamide concentrations were compared (data not shown).

Cells were also identified using the general bacterial probe Eub338 (Amann et al. 1990), a probe specific for the Delaware (DE) cluster 2 subgroup of the Bacteroidetes (Kirchman et al. 2003), 4 probes for the SAR11 clade (Morris et al. 2002), and a negative control probe (Karner \& Fuhrman 1997). The final concentration of probe in hybridization reactions was $2 \mathrm{ng}^{-1}$ per probe, and redundant probes were mixed together to make a single probe cocktail. The same hybridization buffer (900 mM NaCl, $20 \mathrm{mM}$ Tris [pH 7.4], 0.01\% SDS, $30 \%$ formamide) was used for all probes, and hybridization reactions were carried out at $42^{\circ} \mathrm{C}$ for $16 \mathrm{~h}$. Filters were rinsed in a wash buffer $(308 \mathrm{mM}$ $\mathrm{NaCl}, 20 \mathrm{mM}$ Tris [pH 7.4], $6 \mathrm{mM}$ EDTA and 0.01\% $\mathrm{SDS}$ ) for $20 \mathrm{~min}$ at $48^{\circ} \mathrm{C}$ for all probes except the SAR11 probes, which were washed at $55^{\circ} \mathrm{C}$. Filters were mounted on a glass slide with a coverslip using a mounting solution containing 4', 6'-diamidino-2phenylindole (DAPI) (0.5 ng $\left.\mathrm{\mu l}^{-1}\right)$ and a 4:1 mixture of Citifluor (Ted Pella) and Vectashield (Vector Labs). Ten fields of view and a total of 450 to 3000 cells were counted per sample. The negative control probe typically bound to $<1 \%$ of DAPI-stained cells and never bound to more than $2.5 \%$ of DAPI-stained cells.

Leucine assimilation by bacterial groups. The incorporation of ${ }^{3} \mathrm{H}$-leucine by the Polaribacter, RCA Roseobacter, Arctic96B-16, and SAR11 clades was examined using the micro-FISH procedure. Sample collection for micro-FISH analyses during the summer of 2004 were described previously (Kirchman et al. 2007). Briefly, whole seawater (20 to $60 \mathrm{ml}$ ) from 4 locations was incubated in the dark at in situ temperatures for $2 \mathrm{~h}$ with ${ }^{3} \mathrm{H}$-leucine $\left(20 \mathrm{nmol} \mathrm{l}^{-1}\right.$ final concentration; $150 \mathrm{Ci} \mathrm{mmol}^{-1}$, PerkinElmer). These conditions are like those for measurements of bacterial production rates. Incubations were terminated with the addition of paraformaldehyde ( $2 \%$ final concentration) and preserved as described above for FISH analyses. Control samples killed with paraformaldehyde were incubated in parallel with live incubations.

micro-FISH samples were analyzed as described previously (Cottrell \& Kirchman 2003). An exposure time of $48 \mathrm{~h}$ was selected for autoradiography preparations in order to maximize the number of cells associ- ated with silver grains (Kirchman et al. 2007). Ten fields of view and a total of 640 to 1300 cells were counted per sample using a semi-automated image analysis system described elsewhere (Cottrell \& Kirchman 2003).

Nucleotide sequence accession numbers. Sequences of 16S rRNA genes generated in this study were deposited in GenBank under Accession Numbers DQ177819 to DQ177840, DQ184424 to DQ184475, DQ186904 to DQ186970, and DQ200950 to DQ200951.

\section{RESULTS}

To better understand the diversity of bacterial assemblages in the Arctic Ocean, a clone library of 16S rRNA genes was constructed from surface waters north of Alaska. Gene sequences from 139 clones were used for phylogenetic analyses. Of these 139 clones, 127 contained 16S rRNA gene sequences that were distinct from other sequences in the library. Although there were few identical sequences, many of the sequences were highly similar. Indeed, the number of operational taxonomic units (OTUs) dropped from 127 to only 57 when sequences were grouped at a $99 \%$ similarity level. Further grouping at the $97 \%$ similarity level, however, resulted in only a small decrease to 45 OTUs. Estimates of the total diversity of the original sample community were also affected when sequences were grouped at different similarity levels. Using the Chao-1 estimator, diversity in the sampled community decreased from 1976 OTUs to 119 OTUs when sequences were grouped at $99 \%$ similarity, and dropped to 86 OTUs when grouped at $97 \%$ similarity. These results suggest that this Arctic bacterial assemblage was composed of clusters of closely related ribotypes.

The composition of the clone library was determined by assigning clones to various phylogenetic groups based on their closest BLAST hits as well as their positions in a neighbor-joining tree. Surprisingly, $53 \%$ of $16 \mathrm{~S}$ rRNA gene sequences belonged to the Gammaproteobacteria, while nearly all other clones were assigned to either the Bacteroidetes phylum (29\%) or the Alphaproteobacteria (17\%) (Table 2). Of the remaining clones, one belonged to the SAR406 group, whereas the other appeared to be from a Grampositive bacterium. All clone sequences were $\geq 96 \%$ similar to previously discovered 16S rRNA sequences, and $45 \%$ of the clones were $\geq 99 \%$ similar to their closest BLAST hits (Table 2). Interestingly, the closest BLAST hits of $60 \%$ of the clones were to $16 \mathrm{~S}$ rRNA sequences previously found in the Arctic Ocean, although not always from the same region as our library. 
Table 2. Phylogenetic affiliations of 16S rRNA sequences from the Arctic Ocean, showing percent similarity and location of discovery of the closest BLAST hit from GenBank

\begin{tabular}{|c|c|c|c|c|c|}
\hline $\begin{array}{l}\text { Phylogenetic } \\
\text { group }\end{array}$ & $\begin{array}{l}\text { No. of } \\
\text { clones }\end{array}$ & Accession no. & $\begin{array}{c}\text { Closest } \\
\text { BLAST hit }\end{array}$ & $\%$ similarity & Location \\
\hline Gammaproteobacteria & 73 & & & & \\
\hline Arctic96B-16 cluster & 22 & DQ177819-DQ177840 & Arctic96B-16 (AF354595) & 97 & Arctic Ocean \\
\hline Arctic96BD-19 cluster & 11 & DQ184424-DQ184434 & Arctic96BD-19 (AJ400348) & 97 & Arctic Ocean \\
\hline SAR92 clade & 10 & DQ184456-DQ184465 & HTCC2121 (AY386341) & 98 & Oregon coast \\
\hline SAR92 clade & 7 & DQ184435-DQ184441 & Arctic96A-14 (AF354611) & 99 & Arctic Ocean \\
\hline SAR86 clade & 5 & DQ184451-DQ18445) & EBAC31A08 (AF268219) & 98 & Monterey Bay \\
\hline SAR86 clade & 4 & DQ184447-DQ184450 & Arctic97A-18 (AF354613) & 99 & Arctic Ocean \\
\hline \multirow[t]{4}{*}{ SAR86 clade } & 1 & DQ184466 & PI_RT131 (AF354613) & 96 & Plum Island Sound \\
\hline & 3 & DQ184444-DQ184446 & HTCC230 (AY102027) & 97 & Oregon coast \\
\hline & 2 & DQ184442-DQ184443 & EB080-L11B01 (AY627383) & 98 & Monterey Bay \\
\hline & 2 & DQ184473-DQ184474 & ARKDMS-3 (AF468270) & 99 & Arctic pack ice \\
\hline Shewanella & 1 & DQ184468 & S. frigidimarina (U85902) & 99 & Antarctic coast \\
\hline \multirow[t]{5}{*}{ Pseudoalteromonas } & 1 & DQ184469 & P. atlantica (AB049728) & 98 & Antarctic sea ice \\
\hline & 1 & DQ184470 & PI_RT172 (AY580758) & 98 & Plum Island Sound \\
\hline & 1 & DQ184471 & F2 (AY375114) & 97 & Deep sea sediment \\
\hline & 1 & DQ184472 & ZD0433 (AJ400356) & 98 & North Sea \\
\hline & 1 & DQ184467 & Arctic96B-1 (AF353242) & 99 & Arctic Ocean \\
\hline Bacteroidetes & 41 & & & & \\
\hline Polaribacter & 12 & DQ186943-DQ186954 & Arctic97A-15 (AF354620) & 99 & Arctic Ocean \\
\hline Polaribacter & 3 & DQ186955-DQ186957 & G1112S4A (AY353814) & 99 & Southern Ocean \\
\hline AGG58 branch 1 & 8 & DQ186927-DQ186934 & PLY-P3-20 (AY354750) & 97 & UK coast \\
\hline AGG58 branch 2 & 8 & DQ186935-DQ186942 & Arctic97A-17 (AF354617) & 97 & Arctic Ocean \\
\hline \multirow[t]{8}{*}{ AGG58 branch 2} & 1 & DQ186962 & PLY-P1-61 (AY354714) & 97 & UK coast \\
\hline & 2 & DQ186959-DQ186960 & PI_RT283 (AY580573) & 98 & Plum Island Sound \\
\hline & 2 & DQ186963; DQ186967 & Arctic97A-13 (AF354618) & 99 & Arctic Ocean \\
\hline & 1 & DQ186961 & PI_4a4g (AY580638) & 99 & Plum Island Sound \\
\hline & 1 & DQ186964 & PI-4j12f (AY589583) & 100 & Plum Island Sound \\
\hline & 1 & DQ186965 & ZD0203 (AJ400340) & 98 & North Sea \\
\hline & 1 & DQ186966 & 33-PA63B98 (AF469375) & 99 & Juan de Fuca Ridge \\
\hline & 1 & DQ186968 & Arctic96B-24 (AF354616) & 99 & Arctic Ocean \\
\hline Alphaproteobacteria & 23 & & & & \\
\hline SAR11 clade & 4 & DQ186913-DQ186916 & HTCC1062 (AF510192) & 99 & Oregon coast \\
\hline SAR11 clade & 2 & DQ186924; DQ186926 & Arctic97A-1 (AF353228) & 99 & Arctic Ocean \\
\hline SAR11 clade & 2 & DQ186921-DQ186922 & PI_4z11e (AY580520) & 99 & Plum Island Sound \\
\hline SAR11 clade & 1 & DQ186923 & Arctic95B-1 (AF353214) & 97 & Arctic Ocean \\
\hline SAR11 clade & 1 & DQ186925 & Arctic96A-7 (AF353226) & 99 & Arctic Ocean \\
\hline Roseobacter clade & 6 & DQ186904-DQ186909 & Arctic96A-1 (AF353235) & 98 & Arctic Ocean \\
\hline Roseobacter clade & 3 & DQ186910-DQ186912 & NAC1-19 (AF245628) & 99 & North Atlantic Ocean \\
\hline Roseobacter clade & 1 & DQ186917 & Roseobacter sp. (AY697886) & 99 & Antarctic Coast \\
\hline \multirow[t]{3}{*}{ SAR116 clade } & 1 & DQ186919 & Arctic96A-18 (AF353233) & 98 & Arctic Ocean \\
\hline & 1 & DQ186918 & BSBf3-20/40m (AY360524) & 97 & Black Sea \\
\hline & 1 & DQ186920 & PI_RT307 (AY580561) & 99 & Plum Island Sound \\
\hline Other & 2 & & & & \\
\hline SAR406 clade & 1 & DQ200951 & MB13C05 (AY033318) & 96 & Oregon coast \\
\hline Bacillaceae & 1 & DQ200950 & G500K-19 (AF479330) & 98 & Unknown \\
\hline
\end{tabular}

\section{Gammaproteobacteria}

About a third of Gammaproteobacteria sequences were $\geq 97 \%$ similar to clone Arctic96B-16 (Table 2), which was found previously north of Greenland (Bano \& Hollibaugh 2002). Similarly, a cluster of 7 SAR92 sequences were 99\% similar to Arctic96A-14 and
Arctic97A-6 clones, which were also found in Arctic waters (Bano \& Hollibaugh 2002) (Fig. 2). The SAR86 clade accounted for $6 \%$ of the total library and contained sequences $98 \%$ similar to those in Oregon and Massachusetts coastal waters as well as to a proteorhodopsin-containing BAC clone (EBAC31A08) from California coastal waters (Béjà et al. 2000). 


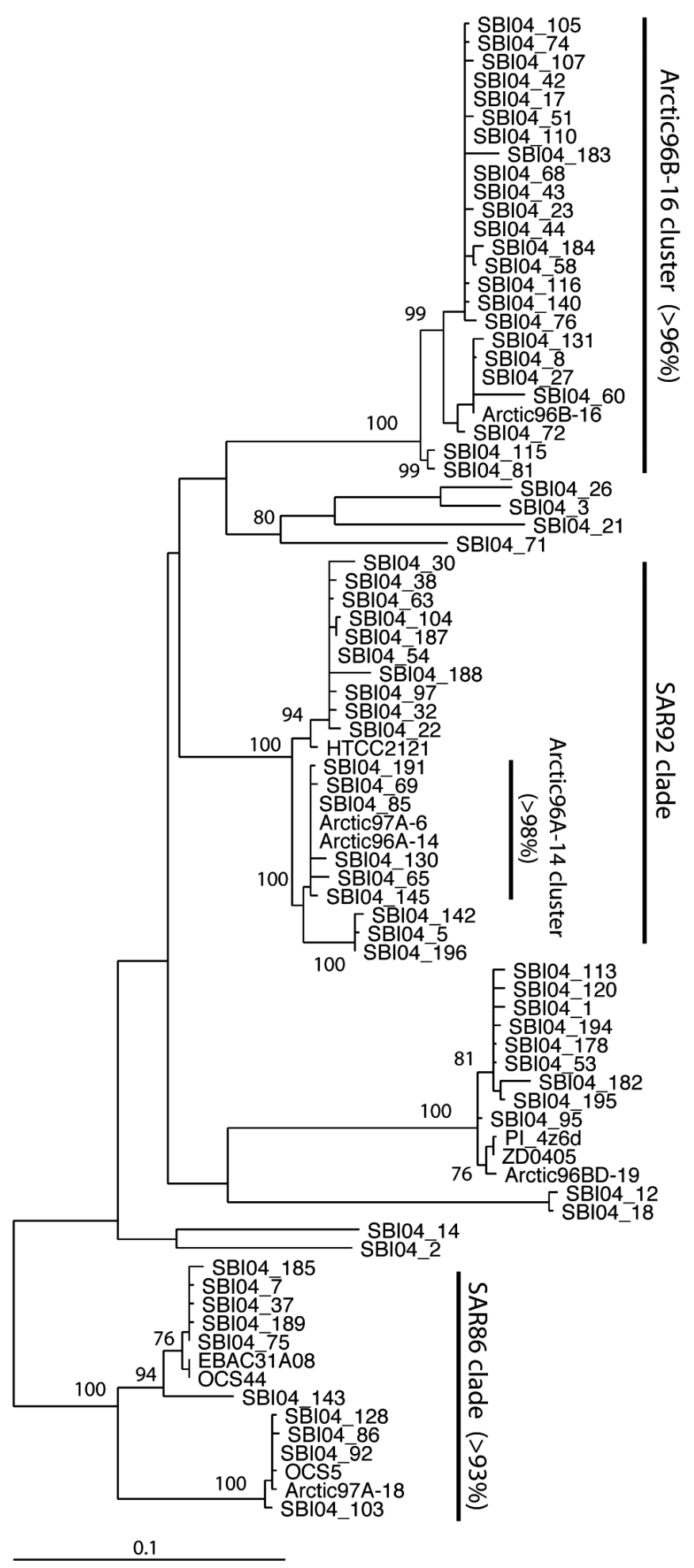

Fig. 2. Neighbor-joining tree of 16S rRNA gene sequences belonging to Gammaproteobacteria in the Arctic Ocean. Minimum \% sequence similarity of group members is shown in parentheses, and branch nodes with $>60 \%$ bootstrap support (100 replicates) are indicated. Scale bar represents $10 \%$ sequence divergence; SBI04 designates clones from this study

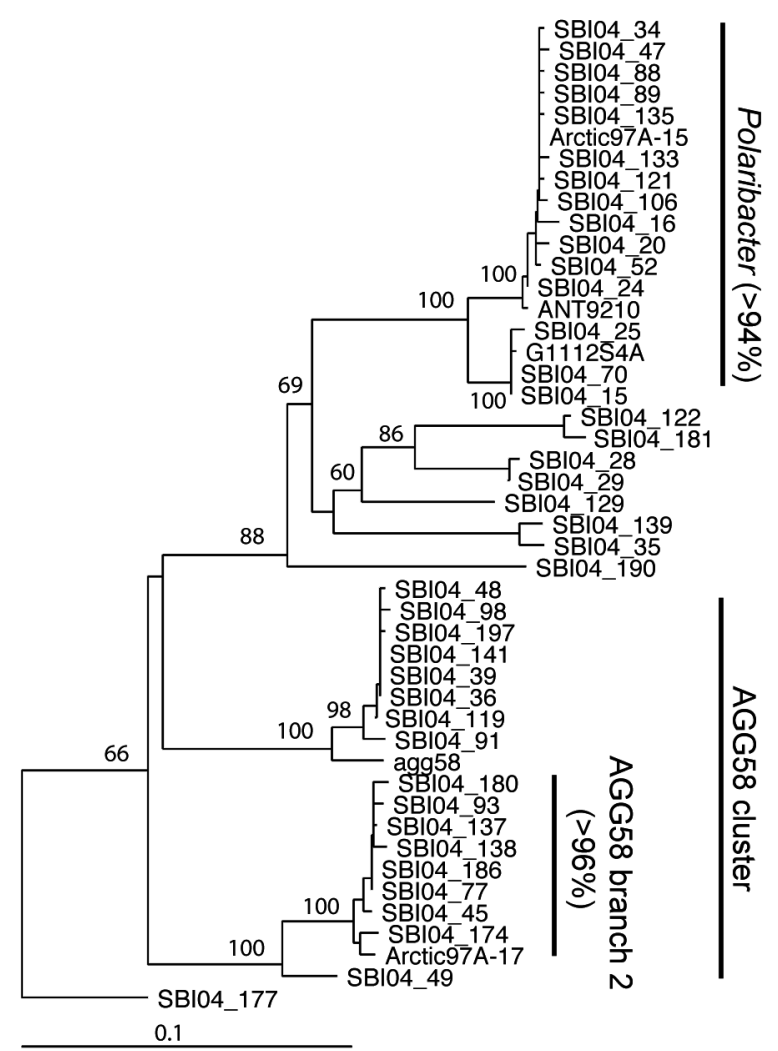

Fig. 3. Neighbor-joining tree of 16S rRNA gene sequences belonging to the Bacteroidetes group in the Arctic Ocean. Further details as in Fig. 2 legend

\section{Bacteroidetes}

Fifteen clones belonging to the Polaribacter group were organized into 2 clusters of $\geq 98 \%$ similarity (Fig. 3). These Polaribacter sequences were 99\% similar to sequences found in the Arctic and Southern Oceans (Table 2). The library also contained 8 sequences from the branch 2 cluster of the AGG58 clade (Table 2). Sequences in the AGG58 branch 2 cluster were $\geq 97 \%$ similar to the Arctic97A-17 clone from the Arctic basin (Fig. 3). The remaining Bacteroidetes clones did not form clusters and had closest BLASTS hits to other clones from the Arctic Ocean, Massachusetts coastal waters, and UK coastal waters.

\section{Alphaproteobacteria}

Of the 23 Alphaproteobacteria clones, 20 belonged to either the Roseobacter or SAR11 clade (Table 2). SAR11 bacteria had an overall sequence similarity of $>87 \%$, and 6 clones were $\geq 98 \%$ similar to Pelagibacter ubique strain HTCC1062 and clone Arctic96A-20 (Fig. 4). Six sequences belonging to the RCA subgroup of the 


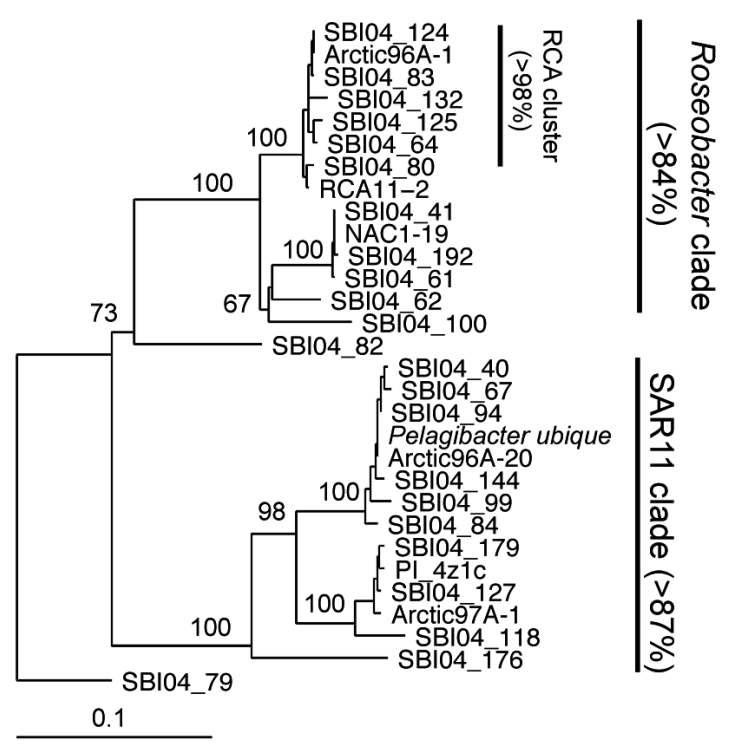

Fig. 4. Neighbor-joining tree of 16S rRNA gene sequences belonging to the Alphaproteobacteria in the Arctic Ocean. Further details as in Fig. 2 legend

Roseobacter, which appears to be restricted primarily to temperate and polar regions (Selje et al. 2004, Pommier et al. 2005), formed a cluster of $98 \%$ similarity.

\section{Quantitative analysis with FISH}

We examined the composition of bacterial communities during different seasons at 25 sites located on the continental shelf and slope, and the Canada basin (Fig. 1). The portion of prokaryotes identified by the general bacterial probe ranged from 57 to $89 \%$, and averaged $75 \%$ across all locations and seasons, indicating that the bacterial assemblages were amenable to FISH analyses (Table 3). By using probes designed for 6 groups found in our library, and probes for the SAR11 and DE cluster 2 clades, $63 \%$ of total prokaryotes could be identified on average (Table 3 ). With the

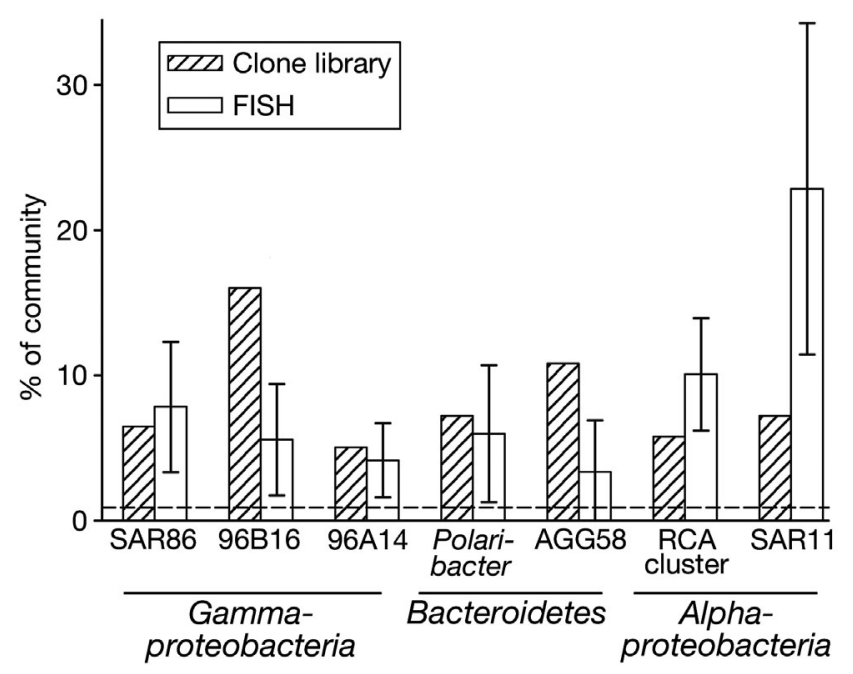

Fig. 5. Abundance of bacterial groups in the Arctic clone library and in the Arctic Ocean as determined by FISH. Results from FISH analyses are mean relative abundance of bacterial groups from all locations and seasons; error bars indicate SD among samples; dashed line represents average percentage of cells binding the negative control probe

exception of the SAR11 clade, 3 to $10 \%$ of total prokaryotes could be assigned to each of the probe groups when averaged over all stations and seasons. Although there was variation among sites, the relative abundance of bacterial groups differed little when grouped by location (shelf, slope, and basin) or season (Table 3). These data suggest that bacterial communities in Arctic waters were largely composed of a few bacterial groups.

Both library and FISH data indicate that the same few groups dominated Arctic bacterial communities. For example, the SAR86 clade, Roseobacter RCA cluster, and the Arctic96A-14 cluster accounted for 7, 7, and $5 \%$ of library clones, respectively, and for $8 \pm 5 \%$, $10 \pm 4 \%$, and $4 \pm 3 \%$ of the total prokaryotic community according to FISH at 25 locations, respectively (Fig. 5). There were, however, some differences between clone library and FISH results. Members of

Table 3. Mean \pm SD abundance of bacterial groups (\% of total community) in the Arctic Ocean determined by FISH, as \% of total cells. Abundances are summarized by region (continental shelf, continental slope, and basin) and by season. Negative control probe hybridized with $1 \%$ of prokaryotes on average. Total = sum of all probe groups, except Eub338

\begin{tabular}{|c|c|c|c|c|c|c|c|c|c|c|}
\hline Sample & Eub338 & SAR86 & 96B-16 & 96A-14 & Polaribacter & AGG58 b2 & DE cluster2 & RCA cluster & SAR11 & Total \\
\hline Shelf & $79 \pm 9$ & $6 \pm 5$ & $6 \pm 5$ & $3 \pm 2$ & $7 \pm 6$ & $3 \pm 3$ & $4 \pm 2$ & $11 \pm 5$ & $22 \pm 15$ & 62 \\
\hline Slope & $71 \pm 21$ & $7 \pm 5$ & $6 \pm 4$ & $5 \pm 3$ & $6 \pm 5$ & $4 \pm 3$ & $4 \pm 2$ & $8 \pm 3$ & $21 \pm 10$ & 61 \\
\hline Basin & $75 \pm 10$ & $10 \pm 4$ & $3 \pm 1$ & $4 \pm 1$ & $3 \pm 1$ & $1 \pm 1$ & $4 \pm 2$ & $10 \pm 4$ & $27 \pm 9$ & 62 \\
\hline Jul-Aug 02 & $75 \pm 12$ & $7 \pm 4$ & $3 \pm 2$ & $2 \pm 1$ & $6 \pm 4$ & $2 \pm 2$ & $2 \pm 1$ & $8 \pm 3$ & $34 \pm 6$ & 64 \\
\hline May-Jun 04 & $80 \pm 9$ & $6 \pm 3$ & $8 \pm 4$ & $6 \pm 3$ & $6 \pm 5$ & $5 \pm 5$ & $4 \pm 2$ & $9 \pm 4$ & $15 \pm 11$ & 58 \\
\hline Jul-Aug 04 & $77 \pm 9$ & $10 \pm 6$ & $4 \pm 2$ & $4 \pm 2$ & $6 \pm 5$ & $3 \pm 3$ & $7 \pm 3$ & $12 \pm 4$ & $21 \pm 6$ & 66 \\
\hline All stations & $77 \pm 10$ & $8 \pm 5$ & $6 \pm 4$ & $4 \pm 3$ & $6 \pm 5$ & $3 \pm 4$ & $4 \pm 3$ & $10 \pm 4$ & $23 \pm 11$ & 63 \\
\hline
\end{tabular}


the DE cluster 2 clade, a subgroup of the Bacteroidetes phylum found previously in the Arctic (Kirchman et al. 2003), were not present in the clone library, but did account for $4 \pm 3 \%$ of bacteria in FISH analyses. The SAR11 clade was the most abundant group in the Arctic, making up $23 \pm 11 \%$ of prokaryotes, but this clade only represented $7 \%$ of clone sequences (Fig. 5).

\section{Leucine assimilation by groups of closely related bacteria}

The contribution of specific bacterial groups to total bacterial biomass production can be estimated using either the fraction of ${ }^{3} \mathrm{H}$-leucine-assimilating cells or the silver grain area associated with each group. Since the 2 approaches did not differ significantly ( $p>0.05$; paired $t$-test), the fraction of leucine-assimilating cells was used to determine contribution to biomass production.

The fraction of total prokaryotes (DAPI-positive cells) assimilating leucine ranged from $46 \%$ on the continental shelf to $12 \%$ in the Canada basin. Together the Polaribacter, RCA Roseobacter, Arctic96B-16, and SAR11 clades accounted for a substantial fraction of both the total community and the total biomass production at 4 locations (Table 4 ). On the continental shelf, for example, half of all cells and of bacterial production could be ascribed to these 4 clades. The Roseobacter RCA-subgroup alone accounted for 4 to $23 \%$ of leucine assimilation at the 4 locations in the western Arctic Ocean, and the Polaribacter clade accounted for $<1$ to $22 \%$ (Fig. 6a). Interestingly, the less abundant and less diverse Arctic96B-16 clade (>96\% sequence similarity) was typically responsible for the same portion of bacterial production $(\sim 16 \%)$ as the more abundant and diverse SAR11 clade ( $>87 \%$ sequence similarity).

Regression analysis identified a linear relationship between the percentage of total cells and leucineassimilating cells accounted for by a group (model II

Table 4. Mean $( \pm 95 \% \mathrm{CI})$ combined contribution of the Polaribacter, Arctic96B-16, Roseobacter RCA, and SAR11 clades to total prokaryotic abundance and biomass production at 4 locations in the Arctic Ocean. BP: bacterial production $\left(\mu \mathrm{g} \mathrm{C}^{-1} \mathrm{~d}^{-1}\right)$

\begin{tabular}{|c|c|c|c|}
\hline \multirow{2}{*}{ Location } & \multicolumn{2}{|c|}{$\ldots$ Percentage of } & \multirow{2}{*}{$\begin{array}{c}\text { Total } \\
\text { BP }\end{array}$} \\
\hline & total cells & Leu-assimilating cells & \\
\hline Shelf & $51 \pm 8$ & $51 \pm 10$ & 1.61 \\
\hline Shelf break & $78 \pm 9$ & $82 \pm 12$ & 0.53 \\
\hline Shelf slope & $39 \pm 5$ & $56 \pm 17$ & 0.98 \\
\hline Basin & $20 \pm 5$ & $25 \pm 10$ & 0.07 \\
\hline
\end{tabular}
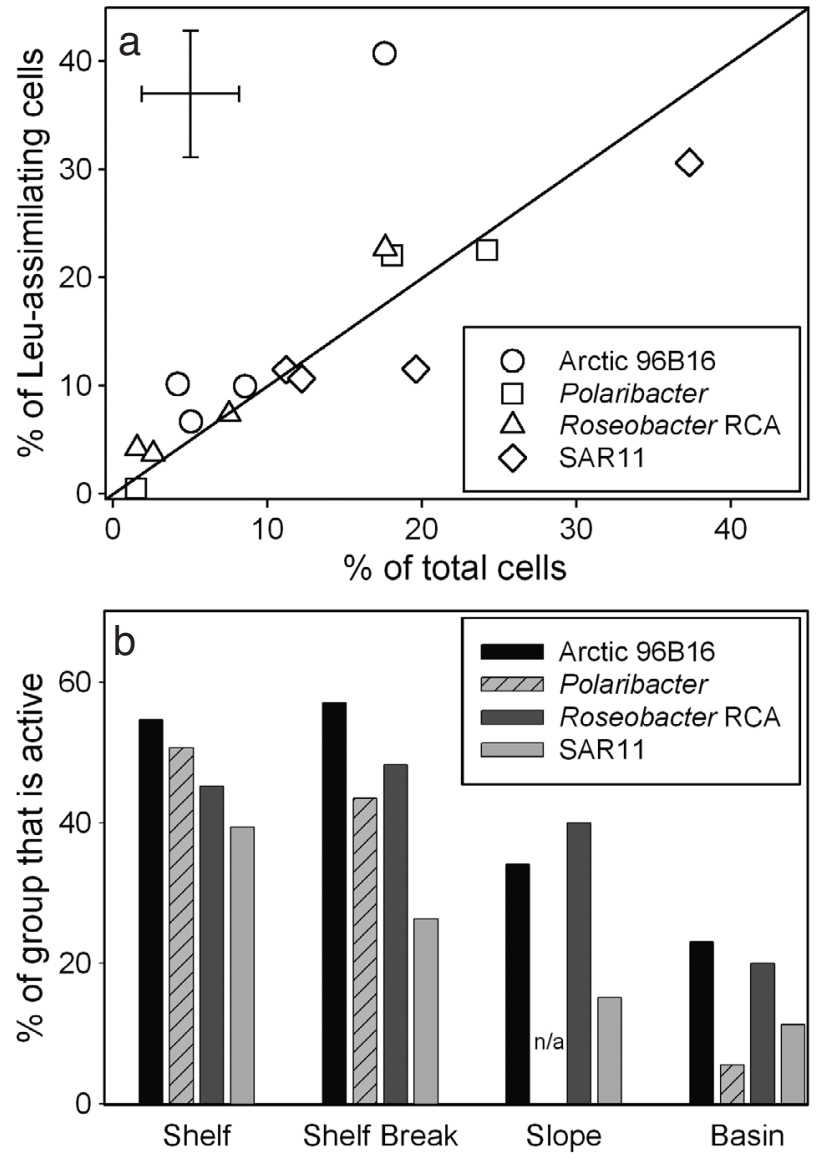

Fig. 6. Contributions of Arctic96B-16, Polaribacter, Roseobacter RCA, and SAR11 clades to biomass production at 4 locations in the western Arctic Ocean. (a) Abundance of various bacterial groups in the leucine (leu)-assimilating community vs. abundance in the total prokaryotic community (DAPI-positive cells); error bars in the upper left corner are the average $95 \%$ confidence limits for all data points; 1:1 line bisects the graph. (b) Fraction of cells within each group that actively assimilated leucine. $\mathrm{n} / \mathrm{a}=$ not available

geometric mean regression; $\mathrm{R}^{2}=0.61$; $\mathrm{p}<0.001$ ), indicating that the contribution of any specific group to bacterial production was determined largely by its abundance (Fig. 6a). However, one notable exception was found at the continental slope station where the Arctic96B-16 group was responsible for $39 \%$ of bacterial production but was only $18 \%$ of the total community (Fig. 6a). These data suggest that a large fraction of total bacterial production in Arctic assemblages can often be ascribed to a few bacterial groups.

In addition to determining the contribution of a group to bacterial production, the micro-FISH data can also be used to examine the fraction of cells within a group that are actively assimilating ${ }^{3} \mathrm{H}$-leucine. A substantial fraction of each bacterial group was actively assimilating ${ }^{3} \mathrm{H}$-leucine, although the percentage of 
active cells tended to be lower in the basin than at the continental shelf and shelf break (Fig. 6b). For example, 55 to $57 \%$ of Arctic96B-16 cells were actively assimilating leucine at the shelf and shelf break stations, whereas only $23 \%$ of cells belonging to this group were active in the basin. In addition, the overall abundance of a group was not related to the fraction of cells within the group that were active (model II geometric mean regression, $\mathrm{R}^{2}=0.01$ ). For example, on the continental shelf, 45 to $50 \%$ of both Polaribacter and Roseobacter RCA cells actively assimilated ${ }^{3} \mathrm{H}$-leucine, yet these groups accounted for a large (24\%) and small $(8 \%)$ fraction of total bacterial community, respectively (Fig. 6b). It appears that factors other than growth rate had a large impact on the abundance of specific bacterial groups at these locations.

\section{DISCUSSION}

Most of the sequences in our Arctic library were $\geq 97 \%$ similar to other bacteria found previously in the Arctic Ocean, consistent with the hypothesis that Arctic bacterial communities differ from those in low latitudes. To better understand the geographic distribution of groups in our library, we used the 'Marine Bacterioplankton Database' (MBD) (Pommier et al. 2005) to determine the locations where similar sequences have been discovered. Sequences belonging to the Arctic96B-16 and Polaribacter clusters from this study were $\geq 98 \%$ similar to sequences in MBD contigs 38 and 665, which have only been found in the polar oceans (Pommier et al. 2005). Bacteria from the Roseobacter RCA cluster and the SAR92 clade live in both temperate and polar regions (Selje et al. 2004, Pommier et al. 2005), but the Arctic96A-14 group forms a distinct phylogenetic cluster within the SAR92 clade, and may represent a primarily Arctic lineage within the SAR92 clade. These results support the hypothesis that Arctic assemblages are distinct from temperate communities and that they contain some phylogenetic groups found only in polar waters.

The relative abundance of major phylogenetic groups in the library examined in this study differs from other marine libraries examined to date. Libraries of $16 \mathrm{~S}$ rRNA sequences from temperate regions are typically dominated by Alphaproteobacteria, while Gammaproteobacteria sequences are usually second or third most abundant (Rappé et al. 1997, Giovannoni \& Rappé 2000, Fuchs et al. 2005). In contrast, Gammaproteobacteria sequences were the most abundant in the Arctic library, and Alphaproteobacteria sequences were the third most abundant. The Arctic library also differs from other libraries because it lacks sequences from other major phylogenetic groups typically found in the oceans, such as the Betaproteobacteria and Actinobacteria. Bano \& Hollibaugh (2002) also did not find representatives of these groups in sequence libraries from the Arctic Ocean. While Betaproteobacteria and Actinobacteria do not typically dominate marine communities (Glöckner et al. 1999, Kirchman et al. 2005), representatives are often present in libraries from temperate regions (Giovannoni \& Rappé 2000, Rappé et al. 2000, Fuchs et al. 2005). The absence of these and other major bacterial groups suggests that bacterial diversity in the Arctic can be lower, at least at a large phylogenetic scale, than in temperate environments.

To address differences between the diversity of Arctic and temperate communities more directly, we compared our Arctic library with a recent library from Massachusetts coastal waters (Acinas et al. 2004). Both libraries were constructed using the same methods to avoid PCR errors, and sequences were determined over the same region of the $16 \mathrm{~S}$ rRNA gene. The number of OTUs in groups with 100, 99, and $97 \%$ sequence similarity was greater in the Massachusetts coastal library than in the Arctic library (Table 5). The Chao-1 estimate of the original number of bacterial sequences in the Massachusetts coastal library was also greater than in the Arctic library. This conclusion is supported by the Shannon-Wiener index calculated at 99 and $97 \%$ sequence similarity, although there was no statistically significant difference at $100 \%$ sequence similarity (Table 5). These data support the hypothesis that Arctic bacterial communities are less diverse than temperate communities. It must be noted, however, that

Table 5. Diversity of bacterial assemblages found in Arctic Ocean and Massachusetts (MA) coastal waters (Acinas et al. 2004). The number of operational taxonomic units (OTUs), Shannon-Wiener index of diversity, and Chao-1 estimator at various \% sequence similarity were calculated from multiple random samplings of 139 sequences from the MA coastal library. Confidence limits (95\%) are provided for the number of OTUs and the Shannon-Wiener index

\begin{tabular}{|lrr|}
\hline $\begin{array}{l}\text { Sequence } \\
\text { similarity (\%) }\end{array}$ & $\begin{array}{c}\text { Arctic } \\
\text { library }\end{array}$ & $\begin{array}{c}\text { MA coastal } \\
\text { library }\end{array}$ \\
\hline OTUs & & \\
100 & 114 & $129 \pm 5$ \\
99 & 46 & $93 \pm 8$ \\
97 & 39 & $80 \pm 8$ \\
Shannon-Wiener & & \\
100 & $4.58 \pm 0.16$ & $4.83 \pm 0.13$ \\
99 & $3.35 \pm 0.18$ & $4.35 \pm 0.15$ \\
97 & $3.05 \pm 0.19$ & $4.12 \pm 0.15$ \\
Chao-1 & & \\
100 & 865 & 1131 \\
99 & 84 & 267 \\
97 & 78 & 188 \\
\hline
\end{tabular}


the community DNA collected for the Arctic library came from the $<0.8 \mu \mathrm{m}$ size fraction, and a lack of sequences from particle-attached bacteria could have led to an underestimate of diversity. More comparisons of similarly constructed libraries are necessary to better understand possible differences in the diversity of bacterial assemblages from Arctic waters and other regions.

One goal of this study was to determine if microbial assemblages in the Arctic were composed of bacterial clusters with high sequence similarity. We found that the number of OTUs in the Arctic library dropped by more than half when sequences were grouped at $99 \%$ similarity, but changed little when sequences were further grouped at $97 \%$ similarity (Table 5). Acinas et al. (2004) reported similar clustering at the $99 \%$ level in a library from Massachusetts coastal waters, suggesting that bacterial assemblages from a variety of environments can be composed of microdiverse clusters and that perhaps this pattern of organization is common to marine bacterial communities. These clusters of highly similar sequences were not found in earlier studies, perhaps because of small library sizes, short sequences, and the presence of spurious sequences resulting from PCR errors (Acinas et al. 2004). Additionally, clones in other studies were often pre-screened with fingerprint techniques to ensure that only distinct clones were sequenced, which would prevent the discovery of microdiverse clusters. Since clusters of high sequence similarity may represent groups of bacteria with similar ecological roles, establishing if this type of clustering is a common feature of bacterial communities is essential for a better understanding of the relationship between the composition of bacterial assemblages and biogeochemical activity.

It is unclear which factors are most important for determining the abundance of bacterial groups in the Arctic Ocean. In this study, the abundance of specific bacterial groups was not strongly correlated with the percentage of active cells within these groups, suggesting that the abundance of these groups was greatly influenced by factors other than growth rate. Similar results were found in the Delaware estuary where the abundance of Alphaproteobacteria, Gammaproteobacteria, and Cytophaga-like bacteria was not strongly correlated with growth rates (Cottrell \& Kirchman 2004, Yokokawa et al. 2004). Cottrell \& Kirchman (2004) hypothesized that top-down pressures such as grazing and viral lysis might explain the low correlation between abundance and growth rates in the Delaware estuary. Mortality from grazing and viral lysis may also influence the structure of Arctic communities by selectively removing the faster growing bacterial groups (Fuhrman 1999, Suzuki 1999).
Rates of mortality from viral lysis in the Chukchi Sea can be equivalent to $10-23 \%$ of bacterial production (Steward et al. 1996), and protists can consume 4 to $30 \%$ of bacterial production $\mathrm{d}^{-1}$ in the central Arctic Ocean (Sherr et al. 1997), indicating that grazing and viral lysis could have a substantial impact on the abundance of various bacterial groups in Arctic waters.

One challenge in understanding the ecology of bacterial communities is to determine which of the bacteria comprising these diverse communities dominate the flux of dissolved organic matter (DOM). Earlier studies focused on the contribution to biomass production by major groups such as the Alphaproteobacteria, Gammaproteobacteria, and Bacteroidetes (Cottrell \& Kirchman 2003, Longnecker et al. 2006, Zhang et al. 2006), which are broad groups on the level of a 'phylum' or 'class'. The contributions of more specific bacterial groups were examined in this study. For example, Roseobacter RCA clade is a single cluster containing sequences with $\geq 98 \%$ similarity, whereas the SAR11 clade, which was the most diverse group analyzed with micro-FISH, is made up of 4 to 5 clusters containing sequences with $\geq 98 \%$ similarity (Acinas et al. 2004, this study). When the clusters that make up the groups examined with micro-FISH are added together, we find that 25 to $82 \%$ of bacterial production can be ascribed to only 10 to 11 clusters. If the common cutoff of $\geq 97 \%$ 16S rRNA gene sequence similarity for a bacterial 'species' is applied, then just 10 to 11 clusters typically accounted for most of bacterial production in this study. This suggests that although the diversity of bacterial communities is high, at any one time only a few microdiverse clusters may be responsible for most of the DOM flux. The next challenge is to examine the specific organic compounds consumed by these bacterial clusters, and determine if the closely related members of these clusters display phenotypic similarities.

Acknowledgements. We thank L. Yu for assistance with clone library construction and FISH analyses, and K. Preen, A. Parker, and our SBI colleagues for help with sample collection. We also thank S. Gonzalez-Acinas and M. Polz for providing aligned sequences for the MA coastal library. This work was supported by a grant from the NSF (OPP 0124733) as part of the Shelf Basin Interaction program. An NSF Graduate Research Fellowship provided support for R.R.M.

\section{LITERATURE CITED}

Acinas SG, Klepac-Ceraj V, Hunt DE, Pharino C, Ceraj I, Distel DL, Polz MF (2004) Fine-scale phylogenetic architecture of a complex bacterial community. Nature 430:551-554

Amann RI, Krumholz L, Stahl DL (1990) Fluorescent oligonucleotide probing of whole cells for determinative, phylogenetic, and environmental studies in microbiology. J Bacteriol 172:762-770 
Amann RI, Ludwig W, Schleifer KH (1995) Phylogenetic identification and in situ detection of individual microbial cells without cultivation. Microbiol Rev 59:143-169

Bano N, Hollibaugh JT (2002) Phylogenetic composition of bacterioplankton assemblages from the Arctic Ocean. Appl Environ Microbiol 68:505-518

Béjà O, Aravind L, Koonin EV, Suzuki MT and 8 others (2000) Bacterial rhodopsin: evidence for a new type of phototrophy in the sea. Science 289:1902-1906

Cohan FM (2002) What are bacterial species? Annu Rev Microbiol 56:457-487

Cole JR, Chai B, March TL, Farris RJ and 7 others (2003) The Ribosomal Database Project (RDP-II): previewing a new autoaligner that allows regular updates and the new prokaryotic taxonomy. Nucleic Acids Res 31:442-443

Cottrell MT, Kirchman DL (2000) Community composition of marine bacterioplankton determined by 16S rRNA gene clone libraries and fluorescence in situ hybridization. Appl Environ Microbiol 66:5116-5122

Cottrell MT, Kirchman DL (2003) Contribution of major bacterial groups to bacterial biomass production (thymidine and leucine incorporation) in the Delaware estuary. Limnol Oceanogr 48:168-178

Cottrell MT, Kirchman DL (2004) Single-cell analysis of bacterial growth, cell size, and community structure in the Delaware estuary. Aquat Microb Ecol 34:139-149

Felsenstein J (2004) PHYLIP (Phylogeny Inference Package) version 3.6. Available from J Felsenstein, Department of Genome Sciences, University of Washington, Seattle, WA

Fuchs BM, Woebken D, Zubkov MV, Burkill PH, Amann R (2005) Molecular identification of picoplanton populations in contrasting waters of the Arabian Sea. Aquat Microb Ecol 39:145-157

Fuhrman JA (1999) Marine viruses and their biogeochemical and ecological effects. Nature 399:541-548

Giovannoni S (2004) Oceans of bacteria. Nature 430:515-516

Giovannoni SJ, Rappé MS (2000) Evolution, diversity, and molecular ecology of marine prokaryotes. In: Kirchman DL (ed) Microbial ecology of the oceans. Wiley-Liss, New York, p 47-84

Glöckner FO, Fuchs BM, Amann R (1999) Bacterioplankton compositions of lakes and oceans: a first comparison based on fluorescence in situ hybridization. Appl Environ Microbiol 65:3721-3726

Grebmeier JM, Harvey HR (2005) The western Arctic ShelfBasin Interactions (SBI) project: an overview. Deep-Sea Res II 52:3109-3115

Huber T, Faulkner G, Hugenholtz P (2004) Bellerophon: a program to detect chimeric sequences in multiple sequence alignments. Bioinformatics 20:2317-2319

Karner M, Fuhrman JA (1997) Determination of active marine bacterioplankton: a comparison of universal 16S rRNA probes, autoradiography, and nucleoid staining. Appl Environ Microbiol 63:1208-1213

Kirchman DL (2001) Measuring bacterial biomass production and growth rates from leucine incorporation in natural aquatic environments. In: Paul $\mathrm{JH}$ (ed) Methods in microbiology, Vol 30. Academic Press, San Diego, CA, p 227-237

Kirchman DL, Yu LY, Cottrell MT (2003) Diversity and abundance of uncultured Cytophaga-like bacteria in the Delaware Estuary. Appl Environ Microbiol 69:6587-6596

Kirchman DL, Dittel AI, Malmstrom RR, Cottrell MT (2005) Biogeography of major bacterial groups in the Delaware estuary. Limnol Oceanogr 50:1697-1706

Kirchman DL, Elifantz H, Dittel AI, Malmstrom RR, Cottrell MT (2007) Standing stocks and activity of archaea and bacteria in the western Arctic Ocean. Limnol Oceanogr 52:495-507

Lane DJ (1991) 16S/23S rRNA sequencing. In: Stackbrandt E, Goodfellow $M$ (eds) Nucleic acid techniques in bacterial systematics. John Wiley \& Sons, New York, p 115-148

Longnecker K, Homen DS, Sherr EB, Sherr BF (2006) Similar community structure of biosynthetically active prokaryotes across a range of ecosystem trophic states. Aquat Microb Ecol 42:265-276

Ludwig W, Strunk O, Westram R, Richter L and 7 others (2004) ARB: a software environment for sequence data. Nucleic Acids Res 32:1363-1371

Malmstrom RR, Cottrell MT, Elifantz H, Kirchman DL (2005) Biomass production and dissolved organic matter assimilation by SAR11 bacteria in the Northwest Atlantic Ocean. Appl Environ Microbiol 71:2979-2986

Manz W, Amann R, Ludwig W, Wagner M, Schleifer KH (1992) Phylogenetic oligodeoxynucleotide probes for the major subclasses of proteobacteria - problems and solutions. Syst Appl Microbiol 15:593-600

Morris RM, Rappé MS, Connon SA, Vergin KL, Siebold WA, Carlson CA, Giovannoni SJ (2002) SAR11 clade dominates ocean surface bacterioplankton communities. Nature 420: 806-810

Pommier T, Pinhassi J, Hagström Å (2005) Biogeographic analysis of ribosomal RNA clusters from marine bacterioplankton. Aquat Microb Ecol 41:79-89

Rappé MS, Kemp PF, Giovannoni SJ (1997) Phylogenetic diversity of marine coastal picoplankton 16S rRNA genes cloned from the continental shelf off Cape Hatteras, North Carolina. Limnol Oceanogr 42:811-826

Rappé MS, Vergin K, Giovannoni SJ (2000) Phylogenetic comparisons of a coastal bacterioplankton community with its counterparts in open ocean and freshwater systems. FEMS Microbiol Ecol 33:219-232

Schloss PD, Handelsman J (2005) Introducing DOTUR, a computer program for defining operational taxonomic units and estimating species richness. Appl Environ Microbiol 71:1501-1506

Selje N, Simon M, Brinkhoff T (2004) A newly discovered Roseobacter cluster in temperate and polar oceans. Nature 427:445-448

Sherr EB, Sherr BF, Fessenden L (1997) Heterotrophic protists in the Central Arctic Ocean. Deep-Sea Res II 44: 1665-1673

Smith DC, Azam F (1992) A simple, economical method for measuring bacterial protein synthesis in seawater using ${ }^{3}$ H-leucine. Mar Microb Food Webs 6:107-114

Steward GF, Smith DC, Azam F (1996) Abundance and production of bacteria and viruses in the Bering and Chukchi Seas. Mar Ecol Prog Ser 131:287-300

Suzuki MT (1999) Effect of protistan bacterivory on coastal bacterioplankton diversity. Aquat Microb Ecol 20:261-272

Thompson JR, Marcelino LA, Polz MF (2002) Heteroduplexes in mixed-template amplifications: formation, consequence and elimination by 'reconditioning PCR'. Nucleic Acids Res 30:2083-2088

Venter JC, Remington K, Heidelberg JF, Halpern AL and 19 others (2004) Environmental genome shotgun sequencing of the Sargasso Sea. Science 304:66-74

Yokokawa T, Nagata T, Cottrell MT, Kirchman DL (2004) Growth rate of the major phylogenetic bacterial groups in the Delaware estuary. Limnol Oceanogr 49:1620-1629

Zhang Y, Jiao NZ, Cottrell MT, Kirchman DL (2006) Contribution of major bacterial groups to bacterial biomass production along a salinity gradient in the South China Sea. Aquat Microb Ecol 43:233-241 